\title{
Increasing Competitiveness Through Innovation in an Industrial Enterprise - A Case Study of the Company Massag
}

\author{
Filip Šproch ${ }^{1 *}$, Jan Nevima ${ }^{1}$ \\ 1 Department of Mechanical Technology, Faculty of Mechanical Engineering, VŠB - Technical University of \\ Ostrava, Faculty of Mechanical Engineering, 17. listopadu 2172/15, 70800 Ostrava-Poruba, Czech Republic \\ *Corresponding author's email: filip.sproch@vsb.cz
}

\begin{abstract}
The paper focuses on the definition of innovation and innovation process from the historical and today's perspective of the Massag engineering company. In order to analyse the innovation process, a SWOT analysis was performed, and, based on the results obtained, the correlation between the results of the analysis and the statistics of innovation activities in the Czech Republic was made. Within the historical analysis of the company, key innovation milestones were identified and described. The main finding was the combination of the use of different types of innovation activities, which plays an important role in terms of the access to innovations and it is necessary to take innovation as a whole, composed of sub-types of innovation that permeate the whole society. The results of the SWOT analysis showed that the main factor that affects the success of the organization and innovation is the long history of the company and knowledge of the markets. This is reflected in the long-term and quality customer relationships. These established contacts with other companies engaged in engineering production are strengths, which are today reflected in the opportunities for further development of the company. The correlation between results and statistics shows that SMEs are forced to innovate because they are under constant pressure from competitors and the market. Therefore, innovation activities are essential for these companies and play a significant role in their current and future competitiveness.
\end{abstract}

Keywords: innovation; industry; SWOT analysis; competitiveness

\section{INTRODUCTION}

The business environment of the global market is permanently changing. New technologies are constantly coming to the market, legislation is continuously changing, while the issue of environmental protection and sustainability and its close links in industry is becoming more and more important. These global conditions force companies to constantly develop new products and services to meet current customer requirements and be able to respond to their needs, which can also be seen as a manifestation of corporate competitiveness. Therefore, the ability of companies to innovate becomes the most important factor for competitive advantage under highly turbulent market conditions [1]. The innovation potential leads companies to constantly develop new innovations, which thus respond to the changing market situation [2] and are integrated into all strategies, systems and structures that support the development of innovation in the company [3]. Innovation enables companies to protect themselves from the uncertainty that is naturally created in the global environment, which ultimately makes them more suitable for finding new opportunities and making effective use of the existing opportunities [4]. Innovations are absolutely indispensable for all companies on the market. The technological production of a company and its ability to identify, share and apply knowledge directly affects its competitive advantage [5]. Companies, whether domestic or international, have included innovation activities in their visions and perceive them as a key mission. 
A competitive company does not wait for the product market to be saturated and demand to decline, which is associated with the reduction in sales, but seeks to anticipate these situations so that it is ready to respond flexibly and effectively in advance and maintain its current "advantageous" position on the global or domestic market, compared to the competing companies. The basis of innovation is the ability to perceive the context and use of market opportunities [6]. Innovation can generally be characterized as a change, renewal or improvement of the current state. This change must always be seen as an opportunity and not a threat. Entrepreneurs must deliberately look for the sources of innovation, changes and their symptoms [7]. Innovation significantly affects the process of globalization. This primarily involves an increase in international competition, which often manifests itself in the form of the flow of goods, services and knowledge across national borders and their interaction. An important function of innovation in the domestic or foreign market is the transfer of technology from the research sector to commercial use.

The aim of this paper was to analyze the impact of the innovation process on the engineering company and the method of SWOT analysis to identify the sources and barriers to further increase the competitiveness of the Massag company and based on these results, assess the correlation between the results of the analysis and statistics of the innovation activities in the Czech Republic.

\section{LITERATURE REVIEW}

This part of the paper is focused on literary research, especially of the foreign sources dealing with the changes in the innovation policy and its role to strengthen the competitiveness of companies and, more importantly, economic systems. The first part of the research is devoted to the very definition of innovation. There is a basis for the theory of innovation and the innovation process in the concept of J.A. Schumpeter, on which a number of contemporary approaches to the definition of innovation are based. The next part of the research defines individual types of innovation, which are further applied to specific real examples.

It can be said that innovations in the general sense of the word have been encountered since the very beginning of civilization itself. Every new invention that mankind has adopted can be considered a kind of innovation. However, we will focus on the modern concept, especially the industrial concept of innovation focused on innovation in the company. Despite the relatively broad concept of innovation policy that we now have, it is very difficult to provide a comprehensive definition of the term, while clearly defining the essence of innovation. However, most of these definitions are based on the Schumpeter's work - The Theory of Economic Development: An Inquiry Into Profits, Capital, Credit, Interest and the Business Cycle. Josef Alois Schumpeter (1883-1950) was an American economist of Austrian origin born in Moravia, who was the first to define the essence of innovation and also systematically dealt with innovation all his life, as the driving force of business activities. However, his idea of innovation was perceived only as the first launch on the market, the so-called absolute innovation.

The Shumpeter's concept of innovation is a combination of these five cases: the introduction of a new product to which consumers are not yet accustomed; the introduction of a new production method not yet used in the sector; opening up a new market that the sector has not previously entered, mastering new sources of raw materials and energy; the emergence of a new organizational arrangement, such as the emergence or demise of a monopoly [8]. Schumpeter promotes a dynamic and long-term analysis of economic problems, connecting economics with history and sociology. Schumpeter assumes that the entrepreneur will de facto discover a gap in the market. This gap suggests to him that if he fills it, he can make large profits on it. Therefore, the entrepreneur is not driven by some ingenious idea of the invention, but by the desire to fill a gap in the market and make money on it. His motivation is his future business profit. The penetration of a new product is not only a technical, but above all an economic innovation. The entrepreneur is looking for an optimal variant that is faster and at the same time more flexible. This entrepreneur is not an inventor in the true sense of the word, but rather an innovator longing for profit. Schumpeter mentions two theories of the concept of innovation. According to the first theory, the key source of innovation is represented by the entrepreneurs who have the so-called creative spirit (the so-called Mark I model). According 
to the second theory, the main source of innovation is represented by large, capital-strong companies that have resources for research and development (the so-called Mark II model) [8]. Schumpeter thus developed the theories of innovation, especially in the technical field, even though he was an economist in his original profession. His concept of innovation became the basis for the emergence of modern concepts of innovation. Schumpeter thus correctly estimated the importance of innovations, and as their number increased, so did their very influence on the further development of individual companies. In today's globalized world, where the very survival of economies is decided by the effective use of innovation, Schumpeter's concept can be understood as a general development framework for a number of economic considerations. Schumpeter's theory of innovation became the basis for the emergence of new definitions for other authors as well. For example, the Thompson [9] defined innovation as follows - innovation takes place in generations, by adopting and implementing new ideas, product or service processes. Innovation is seen as a useful result of the ability of companies to generate new knowledge and their decision to apply it to new products and a variety of products, processes, organizational designs and combinations of inputs and markets $[10,11]$. Innovation can then be understood as the implementation of a new or significantly improved product (goods or services), process, new marketing methods or new organizational methods in business practice OECD [12], it is considered a tool that contributes to increasing the business performance and competitive advantages [13]. Innovation is generally considered to be a key factor in the economic development and competitiveness of companies, regions and countries, so it can be shown that competitiveness as well as innovation are built from the bottom up $[14,15,16,17]$. Anttila and Jussila [18] refer to European Technical Specification CEN / TS 16555-1, which defines innovation as the introduction of a new or significantly improved product (goods or services) or process, new marketing methods or new organizational methods in business practices, workplace organization or external relations [19]. Innovation is a key factor in creating technology and maintaining an organization's competitive advantage, which in turn increases its overall performance [20]. Innovation generally describes the meaning of the evolution of humanity explained in terms of the creativity of the invention as a source of technological, social and cultural change [21]. Innovation is widely recognized as a driving force of the economic growth [22]. Innovation is defined by Dziallas as invention and exploitation [23].

Each of the authors views innovation with a slightly different metric, but in one case the authors agree that innovation brings a certain competitive advantage and is an integral part of the life cycle of a successful company.

So why are we innovating?

- Innovation capacity is defined as a systematic and central process leading to the economic growth, providing and maintaining a competitive advantage to both firms and states [24, 25, 26, 27].

- Innovation activity is a means of expanding the market share [28, 29].

- Innovation is closely related to quality, these two concepts are important business factors for success in all types of companies and positively contribute to sustainable development [18].

- Technological progress depends on a combination of the existing ideas, where companies combine the existing skills with their own ideas to create new, patentable technologies [30].

\section{TYPES OF INNOVATION}

Today, innovation is an integral part of company policy. The purpose of innovation for companies is to achieve their ability to prosper, be successful in the field of competition and create new opportunities. Innovative impulses should be the production, research and development department, as well as marketing and sales staff, but often innovative stimuli also come from other company departments. Marketing research is the basis of every innovation. The innovation survey is future-oriented to meet the expectations and needs of customers over a period of several years. It is necessary to understand the innovation process as a whole composed of separate parts, because today's market situation identifies the introduction of new products (the so-called product innovation) as the main manifestations of innovation. Although innovation is a sophisticated system and process, marketing and organizational innovation is equally important for the company. 


\section{Product (manufacturing) innovation}

Product innovation is made available to potential users, it is a new or significantly changed product in terms of its characteristics or other intended use [31]. Product or service innovation these can be significantly improved performance characteristics, such as technical specifications, integrated software, or other useful features over an existing product or service OECD [12].

Product innovation introduces a completely new product on the market, or a significantly improved product; the same applies to the service. Product innovation makes use of the improvements in technical specifications, such as individual components or materials, as well as software improvements, user-friendliness, and many other functional characteristics. These product innovations are sold directly to the customer, as opposed to process innovations. Thus, the main goal of product innovation is to introduce new products and new product types that will allow the company to gain at least a temporary monopoly position, which gives it some freedom and space to set prices above marginal costs [32]. The product innovation process describes the individual phases of the entire product life cycle in a broader sense, from research to marketing, see Figure 1.

- Cost reduction (this modification permanently changes the price of the product in order to reduce the costs over the competition and does not affect the appearance or other features of the product). For example, in 2010, Nintendo reduced the price of its Wii product, making it more accessible to consumers in the market. The move has attracted the media attention and increased the Nintendo's market share in video games [34].

- Product improvements (this modification improves the existing features of the product and is thus newly offered to the customer). An example is the frequent advertising of many products, which often begins with the words "Now we offer an even better stain degreaser than ever before."

- Extension of the existing functions. An example is a computer program where new functions (plug-ins) are constantly added and offer improvements.

- New markets (product expansion with minimal changes to new markets). An example today includes all car manufacturers that are trying to sell their car overseas. Lynk \& Co is a Chinese carmaker that in 2019 began producing cars for the European market in Belgium.

- New uses (original product placed in new markets with minimal changes).

- New categories (products that are new to the company, but not as categories). For example, Soundbars are new items in the surround sound category [35].

- New products in the world (these are new products that are being launched on the market). An example is the field of healthcare and the discovery of a new drug for tuberculosis [36].

Product innovation is also related to the service innovation, which Toivonen and Tuominen [37] defined as a new service or renewal of an existing service that is implemented into practice and benefits the organization that developed it; the benefit usually results from the added value that this renewal provides to customers. Examples of product innovations include: the first portable MP3 player, the introduction of the Anti-lock Braking System (ABS), the Global Positioning System (GPS) and other improved subsystems in cars, or the introduction of a new service as a "mail partner" at Česká pošta.

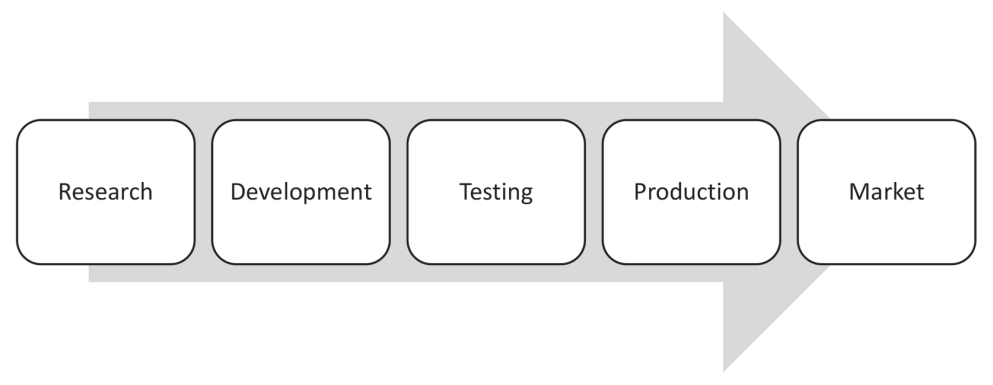

Figure 1. Innovation process.

Product innovation can be divided into seven types [33]: 


\section{Process innovation}

Process innovation is the implementation of a new or significantly changed production or delivery process. This includes significant changes in inputs, infrastructure within the institutional unit and technology [31]. Process innovation is the improvement of a production process aimed at enhancing the productivity of inputs, e.g. in the labour market. The company is thus able to produce the same level of production with fewer employees. Therefore, it is a negative impact of process innovation on employment [38]. Reichstein and Salter [39] define process innovation as new elements introduced into a company's production or service operations - input materials, task specifications, workflow mechanisms, information and equipment used to produce a product or provide services in order to achieve lower costs and / or higher product quality.

Process innovation is of an operational nature, it represents the introduction of a new or significantly improved way of production or provision of services. Process innovations usually do not bring an immediate competitive advantage, but are the basis for gaining a long-term position of the company. Process innovation is the systematic improvement of the activities aimed at eliminating costs or increasing performance. There are a number of methods used, such as Six Sigma, Theory of Constraints (TOC), Lean. The process innovation phase can be divided into three steps. The first phase is to reduce costs and avoid wasting Lean, the second phase is to reduce time, quality, meeting Six Sigma deadlines, and the last phase is to increase the throughput of Theory of Constraints (TOC) bottlenecks. The individual phases are described in Figure 2.

Process innovation introduces a new or significantly modified production process of products or services that improves the company's processes, procedures and strategy depending on the reduction of costs and the increase in the volume of production. Process innovation does not bring immediate utility value as a product, but is the basis for gaining and maintaining the company's long-term position on the market. Every innovation - whether it is entering a market with a new product or adopting a new production process must be intentionally implemented as a part of the company's profit maximization strategy [41]. There is a close relationship between product and process innovation. An example of process innovation can be the introduction of new production methods - inclusion of a new automated machine in the production line introduction of computer aided design, or introduction of a new method of distribution, i.e. a system for tracking goods using bar codes, or Radio Frequency Identification (RFID).

\section{Marketing innovation}

Marketing innovation represents the introduction of a new or significant change in the way of trading, including the way in which the products of an institutional unit are promoted [31]. Marketing innovation is often characterized as

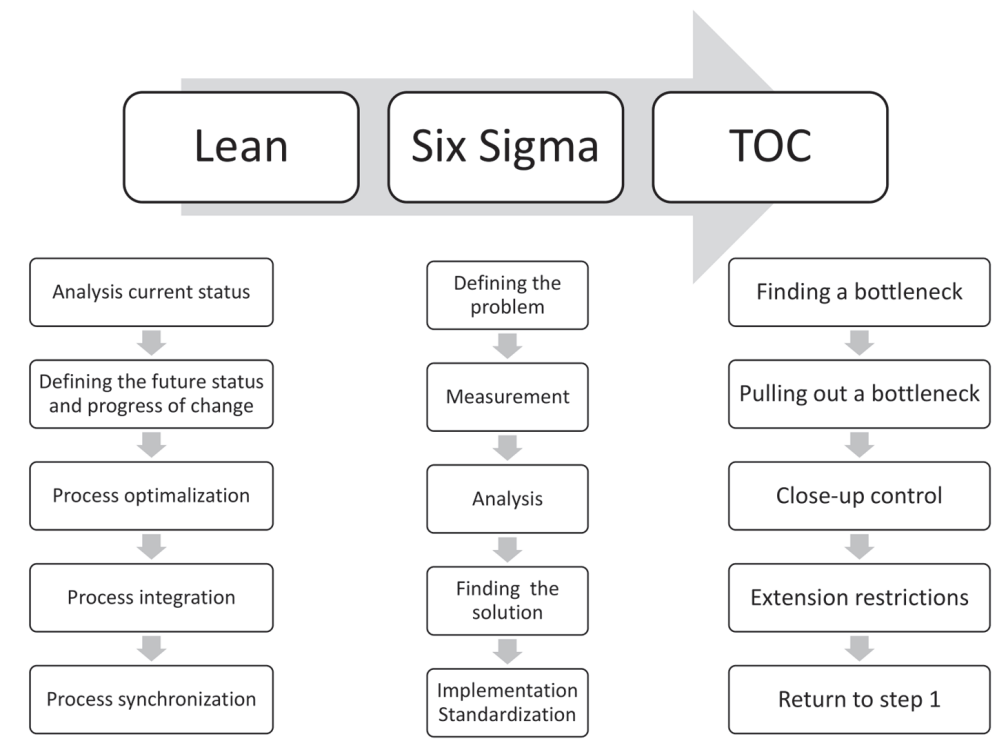

Figure 2. Phases of process innovation. [40] 
improving the mix of target markets, including market segmentation and methods serving those markets [42]. Marketing innovation introduces new marketing methods that involve significant changes in product design, product placement and promotion OECD [12]. These changes in marketing innovation relate to design, packaging promotion, better pricing or the use of new sales methods. Marketing innovation focuses on the requirements of what the customers themselves want. It also involves looking for new markets in which it could start operating or develop the existing markets. The reason for the implementation of marketing innovation is the effort to increase own sales. This method entails the introduction of a new marketing method that the company has not used before. The established method must be a part of a new marketing concept or strategy that is different from the methods that have been used so far. It is employed for new and existing products. The main goal of marketing innovation is to connect with customers and consumers, penetrate new markets or increase sales.

Marketing innovations can be divided into four categories. The following division is according to the Czech Statistical Office ČSU:

- Significant changes in the aesthetic design or packaging of products / services, new packaging, new colour, eco packaging.

- A new way of promoting products / services, the use of the Internet, advertising, introduction of loyalty cards, a new brand image.

- A new way of selling or placing products / services on the market, direct sales, franchising, exclusive sales.

- A new method of valuing products / services, system of discounts.

The first use of a substantially different medium or technique to promote a product in a film or television program is a marketing innovation. Companies such as Google, Zappos, Apple, eBay and Amazon have found innovative ways to solve the customer problems via the Internet by creating new business models for the so-called new age [44].

\section{Organizational innovation}

Organizational innovation represents the introduction of a new or substantially changed way of organization, management, methods in company practice, workplace organization or external relations of an institutional unit [31]. Organizational innovations are the innovations involving the changes in the routine activities of companies aimed at increasing the efficiency, productivity, profitability, flexibility and creativity of the company using imperfect information [32]. Organizational innovation can be defined as the implementation of a new organizational method in business practice or external relationships. Jayani Rajapathirana and Hui [1] these changes and methods are introduced into business procedures, processes, job positions, relationship organizations. It is a fundamental change in the organizational structure or management methods used previously. Organizational innovation increases knowledge, improves the work environment, and reduces administrative costs. At the same time, mergers or acquisitions, even if they occur for the first time, or changes in the management strategy are not considered as organizational innovation, unless they are connected with significant organizational changes. Organizational innovations aim to improve the company's performance by reducing the administrative and transaction costs, as well as improving the workplace satisfaction.

Organizational innovation can be divided into three categories. The following division is according to the Czech Statistical Office [43]:

- New business practices, organization of the supplier-customer relationship management, quality management, ISO standards.

- New methods of organizing human resources, introduction of a new system of employee responsibility, teamwork, training / education systems.

- New methods of organizing the external relations with companies and other institutions, technology transfer to other companies in order to increase their own prosperity.

An example of organizational innovation is the first introduction of the staff development procedures (education and training systems), leading to a reduction in turnover, as well as the first implementation of the production or supply operations management systems (supply chain management systems, enterprise reengineering, lean manufacturing and quality management systems).

These four types of innovation create a basic division which many authors favour. Other types of innovation such as business model innovation and supply chain innovation are mentioned, for example in Kahn [33]. 


\section{Business model innovation}

The innovation of the business model includes new business activities or formulates new approaches to the already established business activities. There are three main types of business model innovation. These types are used alone or in combination; they are innovations in the industrial model, innovations in the revenue model and innovations in business models. The innovation of the industrial model is an innovation related to the value chain. It can be upgraded horizontally. Behind this innovation, there is a shift to new industries, new branches of industries or redefining the existing industries or branches of industries. Examples are Virgin, which started in the music industry and now operates in the aviation or railway industries, or Ryanair, low-cost airline, which represents a completely different cost structure than other companies. The innovation of the revenue model is the generation of revenue by means of a supply way through which revenues flow to the company. An example is Gillette, which sells cheap shaving handles to customers, closing the customer off and then reselling the ever-changing handles to customers.

With the innovation of the company model, the structure of the company changes and the entire value chain is undergoing reconstruction. Uber is an interesting example of business model innovation, as it has changed the taxi industry [33].

\section{Supply chain innovation}

It is a change within the supply chain network, supply chain technology or processes in the supply chain, or a combination thereof, within a company, industry or supply chain in order to enhance the creation of a new value for stakeholders [33]. An example is Vega, which seeks to support, owing to supply chain innovation, the coffee farmers in remote areas who do not have access to the market and have to rely on traffickers to pay them only a small part of the profits.

When implementing any innovation, it is important to take into account all the contexts and issues that this innovation will address. Successful innovation involves a combination of all types of innovation and penetrates the entire company structure, see Figure 3.

On the basis of the research, it is quite clear that in order to be competitive and able to adapt effectively to the global conditions of the worldwide market, every successful company must constantly address the innovation activities within business processes. These innovative activities are adapted and chosen by companies according to their production program, in line with the company's vision, and the size of individual companies or geographical location also play a significant role. Therefore, it is not possible to determine the exact procedure for how companies should use the innovation activities. Just as there are countless different definitions of the concept of innovation itself, companies approach different innovation activities in various ways. As we operate in a technical field focused on the engineering industry, I support the European technical specification for innovation according to CEN / TS 16555-1, which defines innovation as the introduction of a new or significantly improved product (goods or services) or process, new marketing methods or new organizational

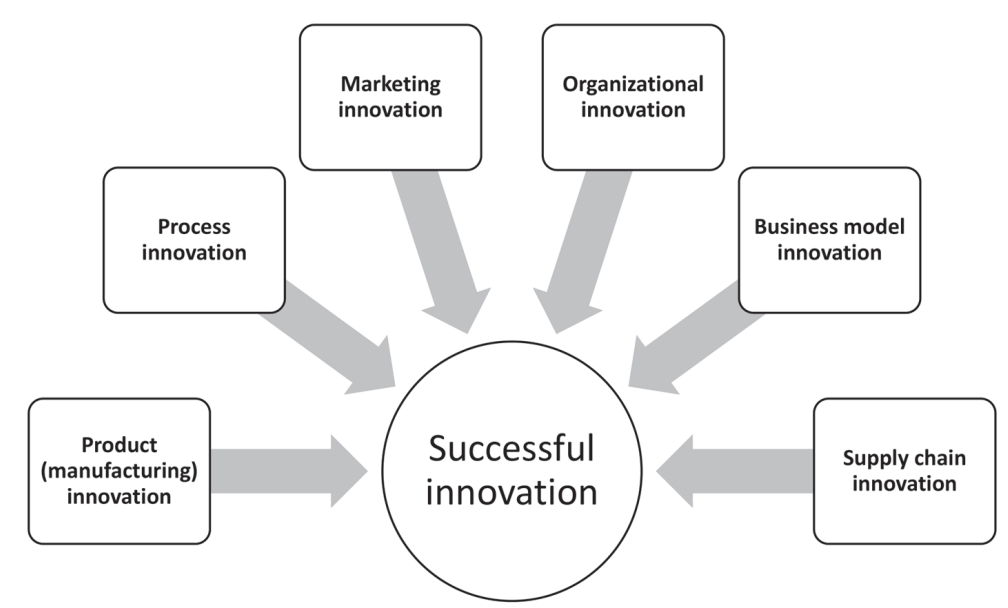

Figure 3. Successful innovation 
methods in business practices, workplace organization or external relations [19]. This definition clearly describes the innovation implemented by individual companies. It is a new or significantly modified measure introduced by the company, whether it is the product or service itself, or any process within the company's activities.

\section{DEVELOPMENT AND IMPACT OF INNOVATIONS IN THE MASSAG COMPANY}

In this part of the paper, our attention will be paid to the results of the innovation process with a focus on the Massag company to which the authors of the paper have long been dedicated. In this sense, it will be the results of the analysis of in-house innovation processes, including their historical excursion. The results are presented here with a description of the most important innovations that the company has gone through in its history and have become important milestones which contributed to the fact that the company has managed to stay on the market to this day.

The Massag company, today based in Bílovec near Ostrava, was founded in 1828 by the Viennese businessman Mathias Salcher in Vienna. The company started operating in Bílovec in 1863 as a branch of Mathias Salcher and Sons. Today, the company in Bílovec operates independently and has been on the market for more than 140 years under the name Massag. This company was founded at the time when it was able to effectively fill the market gap in the weaving industry and was able to seize this opportunity and use the potential that the local market provided. During its presence on the market, the company has constantly changed its approach to innovation processes, which has enabled it to respond adequately and quickly to the changes not only in the market, but also to major global events that have marked the world's history in the years of operation.

\section{The most significant innovations in the company's history}

The very first innovation is the creation of a company. At the beginning of the 19th century, at the time of the still ongoing industrial revolution, Mathias Salcher was able to begin the long history of Massag in 1828 with the production of coarse cotton cloth (canvas).
The main pillar of production before 1900 was the production of buttons from tagua nuts. Here, the company recorded a huge increase in production and sales, when in $1895,1,350$ tons of tagua nuts were brought into the Bílovec factory. This product innovation and the introduction of this product range also resulted in a significant process innovation, when production was mechanized and the first production automated machines were added to the existing machinery. However, the marketing innovation was not left behind either, as it was able to integrate this product from Bílovec not only into the whole of Europe, but also on the market in America or India. This product range has won a number of awards at world industrial exhibitions. This is a clear example of the synergy of innovation management, where product innovation gradually penetrates process innovation, and this innovation in turn penetrates marketing innovation. This process of synergy is important for creating a solid foundation of the company's innovation strategy.

Paradoxically, another impulse of innovation came only with the advent of the First World War. The war brought with it the opportunity of production of a predominantly military nature. However, this meant spending huge capital on innovation activities so that the company could use the potential and reorient its current production to the manufacturing of weapons and equipment components for the military. The company moved smoothly from clothing to military assortment. This innovation was crucial at that time, so the company was able to increase production during the First World War. Furthermore, at this time the company came up with a revolutionary process innovation which consisted in the off-site production of undemanding parts by craftsmen, like today's home-office. Well-managed innovation management in the company gives a certain reserve of possibilities, which in sudden crisis situations, whether geographical, political or natural, will prove to be an initial competitive advantage and the company can use it to strengthen itself.

After the war, it was crucial to identify another business opportunity in a market that was strongly affected by the consequences of the war economy. In addition to the start of the production of pens, which enjoyed great growth and response, the management then saw an opportunity in the volatile market for the production of ski bindings, which began in 1926 and was followed 
in 1930 by the purchase of a Swiss license for Kandahar which at that time was considered the most modern and safest ski binding on the market. This is another example where, owing to timely and successful innovation in an unstable market, it is possible to build a monopoly position which on the one hand creates a certain competitive potential, but from the point of view of imperfect competition, it is not an optimal form of competitive environment.

As the last example of system innovations, we will mention product innovation, when the automotive market developed in 1953, and owing to the development of the car factory in Mladá Boleslav, the production of automotive accessories expanded, thus opening up a new area of production for the company. The product that was behind the success and further continuation of the company was the rear-view mirrors which were installed on the Škoda Favorit car. Here, it is necessary to emphasize that as the individual lines of the Škoda Favorit car changed, so did the rear-view mirrors which underwent constant development, and it was necessary to constantly innovate the product, production process and marketing. Even today, about a hundred pieces of mirrors are produced annually. It can be seen that even today there is a potential market for the customers who are interested in new products that began to be produced thirty years ago. This is mainly a renovation market. One hundred pieces is now a negligible amount, but the company is still trying to capture any opportunity that the market will provide. In addition to the rear-view mirrors, the company also produced the ashtrays built into the dashboard of cars.

These and other innovations have become important milestones in the company's long history, and owing to these innovations, the company still exists today. An overview of key innovations is given in Table 1 .

At present, the Massag company is still based in Bílovec, it employs around 250 employees and continues to manufacture small metal goods, as well as provides surface treatment, when in 1993 a large investment was made in a complex of surface treatment methods, including neutralization of wastewater due to increased environmental and production levels. Since 2006, the production portfolio in the area of handling equipment has expanded. The company started to produce supply cages (Rollkontejnér), trolleys, rudders, there was also an innovation in the area of offering repairs and renovations of shopping trolleys. Furthermore, an innovation of the benefit program for employees is underway.

The Massag company, a.s. has always constantly looked for the opportunities to enter the market and successfully implement individual phases and types of innovations, it was also able to systematically collect data, as well as identify opportunities and threats; thus, it has managed to function successfully to this day.

This analysis of the most important innovations of the company showed the process of a sophisticated system of innovation management, mutual synergy of individual types of innovations, tenacity and benefits of innovation policy at critical world events.

Table 1. The most significant innovation activities of the Massag company between 1828-2020

\begin{tabular}{|c|c|c|c|c|}
\hline Global world events & Year & Innovation & Type of innovation & Impact of innovation \\
\hline & 1828 & $\begin{array}{l}\text { Production of coarse cotton } \\
\text { cloth }\end{array}$ & Product & $\begin{array}{l}\text { Establishment of the company } \\
\text { Start of production }\end{array}$ \\
\hline $2^{\text {nd }}$ Industrial revolution & 1895 & Buttons from tagua nuts & $\begin{array}{l}\text { Product } \\
\text { Organizational } \\
\text { Marketing }\end{array}$ & $\begin{array}{l}\text { Increase in production, sales } \\
\text { Mechanization of production } \\
\text { Market expansion }\end{array}$ \\
\hline \multirow[t]{2}{*}{ The First World War } & 1914 & Military assortment & $\begin{array}{l}\text { Product } \\
\text { Process }\end{array}$ & $\begin{array}{l}\text { Increase in production, } \\
\text { „Homeoffice“ }\end{array}$ \\
\hline & 1926 & $\begin{array}{l}\text { Production of pens } \\
\text { Ski bindings }\end{array}$ & Product & $\begin{array}{l}\text { Increase in production in the } \\
\text { interwar period } \\
\text { Monopoly position }\end{array}$ \\
\hline \multirow[t]{4}{*}{$\begin{array}{l}\text { Worldwide car } \\
\text { production plant }\end{array}$} & 1953 & Rear-view mirror & $\begin{array}{l}\text { Product } \\
\text { Process } \\
\text { Marketing }\end{array}$ & $\begin{array}{l}\text { New production market } \\
\text { (automotive) }\end{array}$ \\
\hline & 1993 & $\begin{array}{c}\text { Complex of surface treatment } \\
\text { methods, Neutralization of } \\
\text { wastewater }\end{array}$ & Process & $\begin{array}{l}\text { Increase in production and } \\
\text { ecological level }\end{array}$ \\
\hline & 2006 & $\begin{array}{l}\text { Handling equipment, } \\
\text { renovation repairs }\end{array}$ & Product & New market area \\
\hline & Today & Employees & Organizational & Motivation schemes \\
\hline
\end{tabular}




\section{SWOT ANALYSIS}

Another part of this paper is devoted to mapping in terms of applying the current possibilities of the company on the market. In order to identify the current possibilities for the Massag company, a SWOT analysis was performed. The expected output of the performed analysis should be the optimization of the company's strategy. Furthermore, it enables evaluate the functioning of the company, identify problems and formulate possible solutions.

A questionnaire method was used to evaluate the current position on the market, which was subsequently reflected in the SWOT analysis. The questionnaire, consisting of 18 questions, was filled in by 150 respondents; afterwards, it was evaluated and elaborated in detail. The questionnaire survey took place in the spring of 2019.

From the evaluation of the introductory part of the questionnaire, we know that 81 women and 69 men were interviewed. Another question was focused on the job position of the interviewee within the company. Here, it was found that employees across the entire structure of the organization, from top management, technical and economic staff, to trained operators at the facilities, completed the questionnaire. The last question in the heading of the questionnaire asked about the number of years worked in the company. The evaluation of this question shows that the employees have worked for the company for 1-25 years, which means that the company also employs new employees, but the core of the company consists of employees with many years of experience, the so-called regular employees. The introductory part of the questionnaire was used to map these basic data and the following part of the questionnaire was devoted to the evaluation of the current market position and to compile a SWOT analysis. Evaluation of the SWOT analysis is presented in Table 2.

\section{Strengths}

The company currently has a well-established customer base with optimally set business relationships. The product range has been constantly changing, and so these customers are from various industries, whether it is the automotive industry, clothing or engineering. Such long-established relationships with customers are related to the very reputation and history of the company. The history and tradition of the company is more than 190 years long. This indicates the long-term activity of the company that overcame the First and Second World Wars. The wars brought with them the opportunities for military production. The company reoriented its current production to the production of weapons and equipment components for the army. The company did not hesitate and smoothly switched from clothing to military assortment and after the war it was able to adapt to the current market again. It follows that the management has always been able to adapt its product to the current market, and thus secure a profit line, even during the difficult war, interwar and post-war periods.

The well-established customer base is also related to the good reputation of the brand in the world, when its products reached not only Europe, but also the USA and India. Today, the company exports the most orders to Asia, mainly small metal goods which are used in the clothing industry. The well-established customer base not only provides the advantage of reference data for conducting business negotiations with potential new customers, but also enables stable production with the possibility of optimizing all related processes.

Unique products were and still are a strong point of the company, in the past it was buttons from tagua nuts or Kandahar ski bindings known all over the world. Today, it is mainly the $\mathrm{Zn} / \mathrm{Ni}$ surface treatment that is experiencing great development, especially in the automotive industry,

Table 2. Evaluation of the SWOT analysis.

\begin{tabular}{|c|c|}
\hline $\begin{array}{c}\text { S } \\
\text { More than 190 years of business tradition } \\
\text { Well-established customer base } \\
\begin{array}{c}\text { Background of other companies in the group dealing with } \\
\text { surface treatment methods- the potential of the cluster }\end{array}\end{array} \begin{array}{c}\text { W } \\
\text { Often outdated production line equipment } \\
\text { Problems with product quality } \\
\text { Dilapidated spaces of buildings }\end{array}$ \\
\hline $\begin{array}{c}\text { Creation of new customer segments } \\
\text { Cooperation with new suppliers and customers } \\
\text { Emerging gaps in the existing market }\end{array}$ & $\begin{array}{c}\text { Tlowdown in the performance of the national economy } \\
\text { Absence of qualified workers for further development of the } \\
\text { company }\end{array}$ \\
\hline
\end{tabular}


or logistics equipment according to the specific wishes of the customer.

The main advantage of this company, which is based on their products, is custom-made manufacturing. Owing to this focus, the company is able to withstand even a very strong competitive environment of large companies. Custom-made manufacturing is more complicated and laborious, but for the customer is able to pay higher price. Unique products are also associated with sophisticated customer service for this sort of products with a reliable planning system.

The company's entire production system meets the ISO standards. The last mentioned strength of the company, which is again based on their products, is the geographical location in Moravia. The automotive industry is widely represented here, which is why the Massag products always reach their customers on time.

Not only the established customer base, but also the background of other companies in the group dealing with surface treatments, such as Lakum-KTL a.s. or Lakum-Galma a.s., gives the possibility of mutual cooperation and there are certain synergies, as a result of which there is a precondition for a future cluster. This will make it possible to improve the transfer of technology from research and scientific institutes directly to the company.

\section{Weaknesses}

Among the weaknesses of the company is the often outdated equipment of production lines. Whether due to natural wear and tear or moral obsolescence, production lines are the cause of the company's lower competitiveness, as in today's world of specific requirements, they are no longer able to provide the required volume of production. It can be said that the outdated equipment of production lines is somewhere on the border between weaknesses and threats, as due to the age of the lines there are more and more problems with securing some spare parts and without modernization of a larger scale, this could cause irreparable line failure in the near future, which could result in the production being stopped, i.e. a situation where the company would not be able to meet its obligations to the customer.

The weakness is also the problem with the quality of products. In order to meet order deadlines, obsolete production lines and systems must constantly produce as many products as possible without breaks, and this is reflected in the final quality of the finished products. Here, it is necessary to capture any poor quality, which in most cases is caused by the instability of the input parameters, resulting from the obsolescence of technological equipment, still inside the company and immediately repair it. This will prevent any poor quality from being reflected in the relationship with the customer.

Another weakness corresponds to the dilapidated spaces of buildings. These buildings were built during the long history of the company and are now largely unused. These spaces interfere with the company's total annual costs. Here, it would be appropriate to use these spaces for new facilities with new products that the market demands with regard to the possibilities and focus of the company, or to offer these spaces for outsourcing production to other companies or as a lease of storage space, and make the maximum possible so that they do not become unused objects, the so-called brownfields [45]

The above-mentioned weaknesses of the company, such as outdated operating equipment, quality problems and dilapidated spaces of buildings, are related to low labour productivity, which is reflected in the structure of the company that can be described as quite rigid.

\section{Opportunities}

Opportunities include the creation of new customer segments, such as new logistics equipment according to the customer requirements, as well as the introduction of repairs and renovations of existing products. A new product is not always accompanied by adequate service support. Another opportunity is to establish cooperation with new suppliers and customers. It is important to realize that the market consists of demand and supply, as well as the producer - customer relationship, so it is important to transfer information not only between the manufacturer and the customer, but also between the manufacturers themselves. Today's situation on the market is influenced by the constant demand for new solutions related to the established products or for completely new unique products. A certain possibility for the company is to implement selected management and production options through SMART solutions which are offered in this area [46].

Another opportunity of the company, associated with the relationship with customers, is 
the cooperation which the company calls "partner-partner", where the company benefits from the fact that together with the customer it "develops" product solutions both "tailor-made" and possibly more advantageous for the customer than originally requested. The company participates in its development and the like, which ultimately leads to the fact that the customer has neither a reason nor an effort to turn to the competition. With regard to the possibilities of custom production, the opportunity can also be seen in one-off projects.

New emerging gaps in the market can be included among the side effects of the constant development and evolution of new technologies. These gaps are in the form of demand for new production technologies and processes, which creates new opportunities.

These business opportunities, such as the emergence of new customer segments, emerging gaps in the existing market, cooperation with new customers and suppliers are closely related and interconnected. Therefore, these opportunities need to be approached systematically and seen as a set of certain interconnected measures.

\section{Threats}

Today, one of the major threats is the impending global economic crisis and the slowdown in economic development, not only in connection with the global economic downturn due to the coronavirus pandemic. This is the greatest problem of restricting free trade, where the Czech Republic is in many ways dependent on direct or indirect exports abroad. When international trade suffers from obstacles, the causes and consequences can be chained, such as rising unemployment, great pressure on public budgets and social problems. The crisis is almost inevitable; nevertheless, it is possible to prepare for it at least partially, but the crisis must not turn into an economic recession. For example, when it is clear that the problem will be exports, it is necessary to focus now on finding domestic customers and new customers and using the potential of market segmentation. Furthermore, it is possible to prepare in advance for a possible sanction that arises from the crisis for the company and start preparing the company for a crisis plan, such as finding the ways to reduce the operating costs or looking for new funding opportunities, including external subsidy programs.
Another threat to the company is its close connection to the automotive industry, the development of which is difficult to predict. Today's car production is stagnating year-on-year. This problem is again related to the impending economic crisis, because the Czech economy is dependent on the development of the automotive industry. Due to the strong export orientation of the economy, the domestic automotive industry is also dependent on the development of the global economy. The difficulties of the world economy could therefore also be reflected in the weakening of the Czech economy. Here, the company needs to look for new opportunities outside the automotive industry.

Another real threat to the company is the very industry in which the company operates, namely the area of metal processing. There is another threat in the form of the development of new materials that replace traditional metals, whether they are new alloys, composite materials, nanomaterials or metal substitutes for plastics. It is not easy to find a solution to this threat. If this threat occurs, one of the solutions seems to be the reengineering of the whole company, and the effort to focus on another possible business sector.

The lack of qualified workers is now a problem in the whole of the Czech Republic, when not only qualified but also young people go to work abroad. With a relatively low unemployment rate, it is difficult to expect a skilled worker to come and apply for a job themselves. Here it is appropriate to provide a safe background for both newcomers and the current employees. Today, employees are looking for a compromise between monetary valuation and a secure company background. That is why it is important to offer this to employees and thus achieve satisfaction on both sides. The trend towards retaining employees or attracting new qualified employees today is almost an obvious offer of employee benefits.

Using SWOT analysis, an analysis of internal and external factors influencing the success of the organization was performed. The analysis was conducted to evaluate the entire organization. On the basis of a questionnaire method that was applied through all levels of employees of the entire company and brainstorming with management, the strengths and weaknesses within the company as well as key opportunities and threats that come from the outside were identified.

On the basis of the performed analysis, it can be said that the production range in the Massag 
company has constantly changed according to the current market requirements. Today, the production portfolio is focused on three basic areas, namely the production of logistics equipment, the production of small metal goods and the provision of surface treatments. It is therefore a market focused on engineering production. A large part of the production is exported abroad and a part of the production is dependent on the automotive industry. From the results of the analysis, it can be inferred that dependence on the automotive industry and emerging problems in free trade abroad are some of the possible threats. The current strategy is relatively vulnerable and it would be appropriate to try to focus on the domestic market. A suitable opportunity can be seen in the mentioned possibility of strengthening, through cooperation with other Czech companies, research organizations, or universities to strengthen their position on the domestic market. For example, the association of companies in a cluster is connected not only with an important information channel, but also with the possibility of obtaining funds.

\section{THE CORRELATION OF THE RESULTS OF THE ANALYSIS WITH THE DEVELOPMENT OF THE INNOVATION ACTIVITIES IN THE CZECH REPUBLIC}

From the results of analysis, we identified the key factors which influence today's innovation activities and competitiveness of the company. In this part of the study, we will assess if the results of the analysis correspond with the development of innovation activities of the Czech Republic. For this purpose, the analysis of the statistics of innovation activities in the Czech Republic for a certain period was performed.
One of the most important indicators, which provide an overview of the state's innovation activities is the share of companies with innovation activity in the total number of companies, the next indicator is a fraction according to size of the company, and a fraction based on the economic activities of particular companies. The statistics were presented for the last 12 years, but the authoritative data for the current innovation activities are data from the recent period.

Table 3 mentioned particular innovation activities of the company for a certain period. The Massag company is today ranked among the medium-sized companies. We can see from the table that in the monitored period approximately $60 \%$ of medium-sized companies in the Czech Republic were engaged in innovation activities. There is a great correlation between the sizes of the companies and their innovation activities. The advantages of small and medium-sized companies in terms of innovation activities, is greater space for innovations because they are more flexible beside the large companies. However, the disadvantage for them is their small capital faces many disadvantages, when they do not have their own research capacity and face financial problems compared to large companies. From the analysis, it can be said that this problem can also be seen at Massag, when in times of the huge boom the company employed about 2000 employees, it had large capital, constantly innovated its manufacturing process, extended manufacturing portfolio and its own producer's base, as well as adapted its manufacture to the current demand. Now, however, the company is many times smaller in terms of the number of employees, but the space has remained and the results is just dilapidated unused space, because the current size of the company does not have enough equity to restore these operations, although its innovation potential is high.

Table 3. Innovative activities of companies in the monitored periods [47]

\begin{tabular}{|c|c|c|c|c|c|c|}
\hline $\begin{array}{ll}\text { Innovative activities [\%] } & \text { Years } \\
\end{array}$ & $\begin{array}{c}2006 \\
- \\
2008\end{array}$ & $\begin{array}{c}2008 \\
- \\
2010\end{array}$ & $\begin{array}{c}2010 \\
- \\
2012\end{array}$ & $\begin{array}{c}2012 \\
- \\
2014\end{array}$ & $\begin{array}{c}2014 \\
- \\
2016\end{array}$ & $\begin{array}{c}2016 \\
- \\
2018\end{array}$ \\
\hline Total innovative companies & 56.0 & 51.7 & 43.9 & 42.2 & 46.3 & 46.8 \\
\hline \multicolumn{7}{|c|}{ According to the size of the company } \\
\hline Small companies & 52.3 & 46.7 & 38.2 & 35.2 & 40.7 & 41.2 \\
\hline Medium-sized companies & 63.5 & 64.0 & 57.6 & 59.1 & 58.2 & 59.8 \\
\hline Large companies & 70.7 & 78.6 & 78.8 & 77.2 & 77.4 & 73.6 \\
\hline \multicolumn{7}{|c|}{ According to economic activity } \\
\hline Industry & 55.4 & 53,2 & 47.1 & 46.0 & 50.5 & 49.4 \\
\hline Services & 56.9 & 49.4 & 39.8 & 37.0 & 41.1 & 43.7 \\
\hline
\end{tabular}


Table 4. Innovation activities of enterprises by type of innovation in monitored periods [47]

\begin{tabular}{|c|c|c|c|c|c|c|}
\hline Type of innovation & $\begin{array}{l}2006 \\
- \\
2008\end{array}$ & $\begin{array}{l}2008 \\
- \\
2010\end{array}$ & $\begin{array}{l}2010 \\
- \\
2012\end{array}$ & $\begin{array}{l}2012 \\
- \\
2014\end{array}$ & $\begin{array}{l}2014 \\
- \\
2016\end{array}$ & $\begin{array}{l}2016 \\
- \\
2018\end{array}$ \\
\hline \multicolumn{7}{|c|}{ Innovative activities [\%] } \\
\hline Businesses with product innovation & 24.5 & 24.1 & 25.3 & 25.1 & 25.7 & 26.8 \\
\hline Businesses with process innovation & 53.3 & 47.2 & 37.9 & 34.8 & 41.7 & 40.3 \\
\hline Businesses with marketing innovation & 35.6 & 29.6 & 22.4 & 20.5 & 26.3 & 22.2 \\
\hline Businesses with organizational innovation & 34.0 & 30.9 & 20.5 & 17.1 & 17.6 & 23.1 \\
\hline
\end{tabular}

The next statistically important indicator of innovation activities are individual types of innovations, table 4 . The innovation activities are divided there to the four basic innovation types, namely products, processes, marketing and organizational innovations.

Table 4 shows that companies use most process innovations. Process innovation is the key source of innovation activities, owing to which it is possible to improve all existing processes within the company, and it is not necessary to spend huge financial resources on new resources.

The last of the important statistic indicators of innovation activities is the market on which are companies, owing to the innovation activities, table 5. There is division into: local market, which is a market at the area of concrete region, where the company affects, national market which is spread over the whole Czech Republic. The third one is national market, which interacts with the neighbour states directly neighbouring with the Czech Republic (Polish, German, Austrian and Slovak market). The fourth group is the whole market in $\mathrm{EU}$, and the last one market is the global market.

Table 5 shows the most important markets for business innovation in the manufacturing industry for the period 2016-2018. The medium-sized companies have the most significant share at the national market, and the smaller one at the global market. It is possible to explain it by small innovation activity of these companies, because of the previously mentioned problem and correlation between small, medium-sized and large companies. Moreover, the market of Massag is now linked primarily on the national market because of the great dependence on automotive segment, however, today's and planned innovation activities are pointed to expansion onto the European or global market.

\section{CONCLUSIONS}

Within the historical analysis of the company, the key innovative impulses that the company went through during its long history were identified and described. On the basis of individual innovations, it can be objectively stated that the company has used various combinations of innovative types throughout history depending on the requirements of the particular time period, and owing to this high adaptability, it was able to survive and remain on the market to this day. This finding is important in terms of approach to innovation because there is a need to take innovation as a whole composed of sub-types of innovation that penetrate the entire society.

From the results of the SWOT analysis, the strengths and weaknesses, opportunities and threats of the company were identified. Nowadays, the company can build on a long history and good knowledge of the markets. Today, the company's innovative knowledge, which has been accumulated over its history, can be used to create a production program that responds to the requirements of the current market. The long-term and high-quality

Table 5. The most important market for business innovation in the manufacturing industry for period 2016-2018 [47]

\begin{tabular}{|c|c|c|c|c|c|}
\hline Enterprise & $\begin{array}{l}\text { Local or regional } \\
\text { market }\end{array}$ & National market & Market & $\begin{array}{l}\text { Local or regional } \\
\text { market }\end{array}$ & National market \\
\hline \multicolumn{6}{|c|}{ For the period 2016-2018 [\%] } \\
\hline Total enterprises & 26 & 39 & 18 & 12 & 5 \\
\hline Small companies & 34 & 44 & 12 & 6 & 4 \\
\hline Medium-sized companies & 17 & 36 & 24 & 17 & 6 \\
\hline Large companies & 8 & 22 & 31 & 26 & 12 \\
\hline
\end{tabular}


relationships with customers and established contacts with other companies engaged in engineering production are strengths that can be used for the benefit of the company today. However, history also brings some weaknesses, which were reflected in the dilapidated production facilities and equipment of the engineering company. The opportunities include emerging new customer segments, cooperation with suppliers and customers, and new gaps in the existing market.

The results of analysis were reflected into current development of innovation market in the Czech Republic, and the linkages between the results of the concrete company and statistic data of the Czech Republic were identified. A direct correlation between the results and statistical data can be seen. These results are important for the company from the point of view of planning, and additional development of innovation activities and its own business of a company. It is also evident that small and medium-sized companied are forced to innovate because they are still under the pressure of competitors and market. From this point of view, the engagement in innovative activities plays a very important role and is a factor in their competitiveness.

The presented paper has offered a number of approaches on how to succeed over a long period on the market through an optimally set innovation process, how to maintain a competitive position on the market, and at the same time the ways how to permanently increase the company's competitiveness over time.

\section{Acknowledgments}

The paper was created with the support of projects No. RPP2020/90 (SPP FR3450021) and No. RPP2020/93 (SPP FR3450031).

\section{REFERENCES}

1. Jayani Rajapathirana R.P, Hui Y. Relationship between innovation capability, innovation type, and firm performance. Journal of Innovation \& Knowledge 2018; 3; 44-55. https://doi.org/10.1016/j.jik.2017.06.002

2. Slater F.S, Hult G.T.M, Olson E.M. Factors influencing the relative importance of marketing strategy creativity and marketing strategy implementation effectiveness. Industrial Marketing Management 2010; 39; 551-559. https://doi. org/10.1016/j.indmarman.2008.03.007

3. Gloet M, Samson D. Knowledge management and systematic innovation capability. International Journal of Knowledge Management 2016; 12; 54-72. https://doi.org/10.4018/IJKM.2016040104
4. Matzler K, Abfalter D.E, Mooradian T.A, Bailom F. Corporate culture as an antecedent of successful exploration and exploitation. International Journal of Innovation Management 2013; 17; 1-23. https:// doi.org/10.1142/S1363919613500254

5. Alavi M, Leidner D.E. Review: Knowledge management and knowledge management systems: conceptual foundations and research issues. MIS Quarterly 2001; 25(1); 107-136.

6. Tidd J, Bessand J.R. Managing innovation: integrating technological, market and organizational change. Hoboken: Wiley; 2005.

7. Drucker P. F. Innovation and Entrepreneurship. Oxford: Elsevier Ltd; 1985. p. 17.

8. Schumpeter J. A. The Theory of Economic Development: An Inquiry Into Profits, Capital, Credit, Interest, and the Business Cycle. Cambridge: Harvard University; 1934.

9. Thompson V.A. Bureaucracy and innovation. Administrative Science Quarterly 1965; 10; 1-20.

10. Fagerberg J, Mowery D.C, Nelson R.R. The Oxford Handbook of Innovation. Oxford University Press: Oxford; 2006.

11. Saridakis G, Idris B, Hansen J.M, Dana L.P. SMEs' internationalisation: When does innovation matter? Journal of Business Research 2019; 96; 250-263. https://doi.org/10.1016/j.jbusres.2018.11.001

12. OECD. Oslo manual: Organisation for Economic Co-operation and Development; Paris 2005. p. 47.

13. Castaño M-S, Méndez M-T, Galindo M-Á. Innovation, internationalization and business-growth expectations among entrepreneurs in the services sector. Journal of Business Research 2016; 69; 1690-1695. https://doi.org/10.1016/j.jbusres.2015.10.039

14. Lancker J.V, Mondelaers K, Wauters E, Huylenbroeck G.V. The Organizational Innovation System: A systemic framework for radical innovation at the organizational level. Technovation 2016; 52-53; 40-50. https://doi.org/10.1016/j.technovation.2015.11.008

15. Frambach R.T, Schillewaert N. Organizational innovation adoption: a multi-level framework of determinants and opportunities for future research. Journal of Business Research 2002; 55; 163-176. https://doi.org/10.1016/S0148-2963(00)00152-1

16. Reinders M.J, Frambach T.T, Schoormans J.P.L. Using product bundling to facilitate the adoption process of radical innovations. Journal of Product Innovation Management 2010; 27; 1127-1140. https://doi.org/10.1111/j.1540-5885.2010.00775.x

17. Tödtling F, Trippl M. One size fits all?: Towards a differentiated regional innovation policy approach. Research Policy 2005; 34; 1203-1219. https://doi. org/10.1016/j.respol.2005.01.018

18. Anttila J, Jussila K. Striving for benefits of sustainability from the interactivity of quality and innovation. Journal of Cleaner Production 2019; 212; 409419. https://doi.org/10.1016/j.jclepro.2018.11.061

19. CEN. CEN/TS 16555-1 Innovation Manage- 
ment - Part 1: Innovation Management System. CEN Brussels: Belgium; 2013.

20. Huang Kuo-En, Wu Jih-Hwa, Lu Shiau-Yun, Lin Yi-Chia. Innovation and technology creation effects on organizational performance. Journal of Business Research 2016; 69; 2187-2192. https:// doi.org/10.1016/j.jbusres.2015.12.028

21. Edwards-Schachter M. The nature and variety of innovation. International Journal of Innovation Studies 2018; 2; 65-79. https://doi.org/10.1016/j. ijis.2018.08.004

22. Qi S. Advertising, industry innovation, and entry deterrence. International Journal of Industrial Organization 2019; 65; 30-50. https://doi. org/10.1016/j.ijindorg.2018.09.006

23. Dziallas M, Blind K. Innovation indicators throughout the innovation process: An extensive literature analysis. Technovation 2019; 80-81; 3-29. https:// doi.org/10.1016/j.technovation.2018.05.005

24. Catherine M, Mitchell B, , Mitchell W. The effect of introducing important incremental innovations on market share and business survival. Strategic Management Journal 1995; 16; 161-182. https:// doi.org/10.1002/smj.4250160922

25. Tushman M.L, O’Reilly C. Ambidextrous organizations: Managing evolutionary and revolutionary change. California Management Review 1996; 4; 8-30.

26. Chen j, Wang Y, Song M, Zhao R. Analyzing the decoupling relationship between marine economic growth and marine pollution in China. Ocean Engineering 2017; 137; 1-12. https://doi.org/10.1016/j. oceaneng.2017.03.038

27. Hu Mei-Chih, Mathews J.A. National innovative capacity in East Asia. Research Policy 2005; 34; 1322 1349. https://doi.org/10.1016/j.respol.2005.04.009

28. Grimpe Ch, Sofka W. Search patterns and absorptive capacity: Low- and high-technology sectors in European countries. Research Policy 2009; 38; 495 -506. https://doi.org/10.1016/j.respol.2008.10.006

29. Damanpour F. Organizational innovation: a meta-analysis of effects of determinants and moderators. Academy of Management Journal 1991; 34; 555-590.

30. Griffith R, Lee S, Straathof B. Recombinant innovation and the boundaries of the firm. International Journal of Industrial Organization 2017; 50; 34 56. https://doi.org/10.1016/j.ijindorg.2016.10.005

31. Gauld F. Defining and measuring innovation in all sectors of the economy. Research Policy 2018; 47; 3; 617-622. https://doi.org/10.1016/j.respol.2018.01.007

32. Tavassoli S, Karlsson Ch. Persistence of various types of innovation analyzed and explained. Research Policy 2015; 44; 1887-1901. https://doi. org/10.1016/j.respol.2015.06.001

33. Kahn K.B. Understanding innovation. Business Horizons 2018; 61; 453-460. https://doi. org/10.1016/j.bushor.2018.01.011

34. Pepitone J. Nintendo slashes Wii price by
20\%. CNNMoney.com; 2009. Available online https://money.cnn.com/2009/09/24/technology/ nintendo_wii_price_cut/index.htm?postversion $=2009092407$

35. Puk J. Samsung: dva nové soundbary řady Q s prostorovým zvukem a optimalizací pro QLED. Avmania.cz; 2019. Available online https://avmania. e15.cz/samsung-dva-nove-soundbary-rady-q-s-optimalizaci-pro-qled-tv

36. ČTK. Univerzita Karlova objevila nové látky proti tuberkulóze, prodala je americké firmě. Aktuálně. cz 2018. Available online https://zpravy.aktualne. $\mathrm{cz/domaci/univerzita-karlova-prodala-amer-}$ icke-firme-vynalez-latek-prot/r c 8269ef8ff0811e8 a0680cc47ab5f122/

37. Toivonen M, Tuominen T. Emergence of innovations in services. The Service Industries Journal 2009; 29; 7; 887-902. https://doi. org/10.1080/02642060902749492

38. Lachenmaier S, Rottmann H. Effects of innovation on employment: A dynamic panel analysis. International Journal of Industrial Organization 2011; 29; 210-220. https://doi.org/10.1016/j.ijindorg.2010.05.004

39. Reichstein T, Salter A.J. Investigating the sources of process innovation among UK manufacturing firms. Industrial and Corporate Change 2006; 15; 653-682. DOI: 10.1093/icc/dt1014

40. Košturiak J, Chal' J. Inovace: vaše konkurenční výhoda!. Computer Press: Brno; 2008.

41. Smirnov V, Wait A. Innovation in a generalized timing game. International Journal of Industrial Organization 2015; 42; 23-33. https://doi. org/10.1016/j.ijindorg.2015.06.003

42. Johne A. Successful market innovation. European Journal of Innovation Management 1999, 1; 6- 11. https://doi.org/10.1108/14601069910248838

43. ČSU. Inovační aktivity podniků. Czso.cz; 2016. Available online https:/www.czso.cz/documents/ 10180/61449086/21300318a.pdf/f43ad817-711b49b5-b032-e91d1c45e7d5?version=1.1

44. Takaoka K. Marketing \& Innovation in the $21 \mathrm{st}$ Century - Kohzoh Takaoka, CEO, Nestlé Japan. The marketing journal; 2017. Available online http://www.marketingjournal.org/marketing-innovation-in-the-2 1 st-century-kohzoh-takaoka-ceo-nestle-japan/

45. Turečková K, Nevima J, Škrabal J, Martinát S. Uncovering patterns of location of brownfields to facilitate their regeneration. Some remarks from the Czech Republic 2018; 10(6); 224-234.

46. Turečková K, Nevima J. The Cost Benefit Analysis for the Concept of a Smart City. How to Measure the Efficiency of Smart Solutions? 2020; 12(7); 2663.

47. ČSU. Inovační aktivity podniků. Czso. Cz. 2020. Available online https://www.czso.cz/document s/10180/122363224/21300320a1.pdf/66912f0f$47 \mathrm{c} 2-47 \mathrm{~d} 0-\mathrm{abb} 2-220 \mathrm{c} 0 \mathrm{~b} 6 \mathrm{~b} 9 \mathrm{a} 32$ ?version $=1.3$ 